\section{Analysis of the Fluctuation of the Number of ISO 9001:2015 Certificates in the Republic of Croatia and Assessment of Satisfaction of Business Organisations Leadership with the Certificate}

\author{
Petar Vušković \\ PhD Student at the University of Zagreb, Faculty of Economics and Business, \\ Croatia \\ pvuskovic@qnorma.com
}

\begin{abstract}
The ISO 9001:2015 certificate of quality is nowadays the most renowned quality standard in the world. Standardised quality has become an imperative competitive advantage on the market for all serious business organisations. The fluctuation of the number of certificates of quality indicates to what extent companies are willing to ensure the quality of their products and services to customers and clients, and how fast the domestic market is standardised and integrated into the global economy. This paper presents the results of two empirical studies. The first one focused on the analysis of the fluctuation in the number of ISO 9001:2015 certificates in the period from 2008 to 2018, while the second aimed to determine the satisfaction of leadership with the certificate. The study has shown that, during the observed period, the number of certificates of quality in Croatia fluctuated between $-18 \%$ and $+22 \%$ annually. At the annual level, a certain number of companies lose their certificates or opt for decertification. For that reason, a study of the leadership's level of satisfaction with the ISO 9001:2015 certificate was conducted using a sample of 296 certified business organisations. The study has proven that the leadership showed a high level of satisfaction with the certificate of quality and that they appreciate business organisations with certificates of quality. It demonstrates that the quality management certification has a bright future regardless of the annual fluctuation of the number of certificates.
\end{abstract}

Keywords: certificate, standard, ISO 9001:2015 certificate, quality system, leadership, business organisations

\section{Introduction}

The fluctuation of the number of certificates was analysed during the period from 2008 to 2018. The analysed data showed an interesting decline in the number of certified business organisations in the aftermath of the global economic crisis of 2008. This was to be expected considering the decline of business activities at the time. In the years following, the number of certificates increased and
ORIGINAL SCIENTIFIC PAPER

RECEIVED: AUGUST 2020

REVISED: OCTOBER 2020

ACCEPTED: NOVEMBER 2020

DOI: 10.2478/ngoe-2020-0022

UDK: 005.954:006.35(100)ISO:005.32(497.5)

JEL: M21

Citation: Vušković, P. (2020). Analysis of the Fluctuation of the Number of ISO 9001:2015 Certificates in the Republic of Croatia and Assessment of Satisfaction of Business Organisations Leadership with the Certificate. Naše gospodarstvo/Our Economy, 66(4), 40-49. DOI: 10.2478/ngoe-2020-0022

\section{NG OE}

NAŠE GOSPODARSTVO OUR ECONOMY

Vol. 66 No.4 2020 pp. $40-49$ 
reached a maximum in 2014, followed by another decline in the number of certificates. The observed trend confirmed significant fluctuations in the number of certificates in the observed period, so an additional study, an analysis of the leadership satisfaction with the ISO 9001:2015 certificate was conducted to determine the level of satisfaction with the implemented quality system or to establish whether the ISO 9001:2015 certificate is appreciated.

The random stratified sample was determined based on the size of business organisations. Three strata were defined (micro, small, medium, and large business organisations observed in a common stratum) with a population of $\mathrm{N}=2529$. The study indicated that $53 \%$ of the respondents showed high satisfaction with the ISO 9001:2015 certificate. Eighty-point-nine percent of respondents had a positive perception of the certificate, i.e. they appreciated business organisations with ISO 9001:2015 certificates. Therefore, it can be concluded that the fluctuations in the number of certificates have not been related to the leadership's dissatisfaction with the certificate of quality.

Business organisations of different sizes have organisational structures and business processes of different complexity, so the initial assumption was that a certified quality system does not create the same positive effects on business activities, which then results in different levels of satisfaction depending on the size of the business organisation. That is why it was tested whether there was a statistically significant difference among the three strata based on the business organisation size in the leadership's satisfaction with the certificate and their perception of the importance of the certificate. The conducted study has shown that there was not a statistically significant difference among various strata of the sample. These results, additionally, confirmed previous positive experiences with certified quality systems.

The research was conducted through an original survey, distributed and collected between March 1st, 2018, and June 1st, 2018. The majority of respondents filled out the survey online via the Limesurvey platform. A minority of the respondents (10\%) filled out the survey through a questionnaire delivered via e-mail as a Word document. The scientific contribution of the article reflected that while current studies created critical outlooks on the benefits gained through certified quality systems, not one earlier research has proven the leadership's satisfaction with the ISO certificate of quality or how they appreciate business organisations with the certificate of quality. The uniqueness of this study lies in the differentiated approach of evaluating the satisfaction of leadership within micro, small, medium, and large business organisations. This is the first research paper that provided scientific confirmation of leadership satisfaction with the ISO certificate of quality along with their perception about it through different sizes of business organisations and various business sectors. This study is also notable because it evaluated the trends in the number of certificates in the observed period and connected this number with the leadership's satisfaction in the quality management system. The paper combined the theory from previously published literature regarding certified quality systems, acquired knowledge and experience from business practice in certified quality systems, and empirical evidence from scientific research. The theme upon which the scientific contribution is built is both modern and contemporary because there is an increasing number of certified business organisations in the world that have implemented a quality management system according to the ISO 9001:2015 standard in their business management.

\section{Literature Review}

ISO 9001:2015 certificates confirm that business organisations have implemented a quality management system into their business operations, i.e. that they have accepted a quality standard. The terms standard and norm are synonyms since the word standardisation means to the norm, i.e. change something into the required size, strength, or approach (Lazibat, 2001). The practical value of the ISO 9001:2015 standard is that through its requirements, it enables business organisations to establish a quality management system that improves their business operations and facilitates participation in international markets. The standard determines the guidelines for quality system improvement (Dumičić, Kunović, \& Dumičić, 2005). The system is defined as a group of interrelated elements (parts, processes, subsystems) that function in line with set rules, aimed at attaining a certain goal, while they also make a relatively independent unit (Zelenika, 2001). Certified quality systems contribute to order, which is based on good organisation, better communication among people, better productivity, reduction of mistakes, satisfied workers who are, consequently, also significantly more productive. It is these positive effects in business activities that have made certification to the ISO 9001:2015 standard popular around the world. For that reason, Croatian business organisations need to be involved in quality certification as much as possible. Certificates are important, also, because they facilitate business operations in the international market by creating trust among buyers, clients, suppliers, and partners. Dumičić, Knego, \& Melvan (2006) have underlined the European perspective of quality development in Croatia. A certificate is imperative for all business organisations that would like to be competitive in the global market. Ćuzović and Ćuzović (2012) studied the importance of quality systems in the internationalisation of 
trade. The purpose of quality certification is to accelerate liberalisation processes important for international trade. Free markets imply business operations based on the same rules and principles, and if business organisations follow them, doing business is, to a large extent, facilitated. Črnjar and Vrtodušić Hrgović (2013) proved that quality certification in tourist companies strengthens their competitiveness, while Zambelli and Rajić (2014) concluded that exportation is the main motivation for quality certification in foreign trade companies. The present paper analyses the fluctuation of the number of certified business organisations, i.e. the number of ISO 9001:2015 certificates because this fluctuation is indicative of how fast the Croatian market is standardised and to what extent customers' and clients' demands are given priority. Dumičić (2004) used a questionnaire to study the implementation of the quality system in Croatian companies. Dumičić, Lazibat, and Matić (2005) used the same questionnaire to determine the implementation of the quality system in Croatian companies in the context of market structure.

Another reason why it is important for as many as possible Croatian business organisations to be certified is the quality measurement. Certificates of quality confirm that the leadership of business organisations measures quality and improves it to meet customers' expectations, and, consequently, customers' satisfaction always results in satisfied leadership as well. According to Gryna and Juran (1999), quality is defined as customer satisfaction. These authors focused their attention on two very important components, a "customer" and a "product." "A customer is anyone who is affected by the product or by the process used to produce the product” (Gryna \& Juran, 1999). Measuring service quality is important if the leadership plans to meet its expectations of the quality system since quality measurement ensures service the provider's satisfaction, sets high standards for services provided to clients, continuously monitors and surveils performance as well as provides feedback to employees (Cronin \& Taylor, 1992; Abu-Kharmeh, 2012). Škafar (2020) studied quality management systems in 30 higher vocational colleges and concluded that the interviewees believed that implementation of the quality management system had contributed to improving the satisfaction of individual members of the college, better implementation of processes, and regular improvements in the college. When a business organisation accomplishes a certain level of quality, benefits for the business organisation are created, which is then reflected in improved efficiency of business processes, higher profitability, and competitive advantage (Benner \& Veloso 2008, 611). Business processes are important because they are the backbone of each quality management system, so one of the main aims of a certified quality system is the development of the process-oriented approach to measurement to remedy non-compliance. A process-oriented organisation ensures the implementation of regular improvements, which can be internal or external. Internal improvements target internal processes and prevent mistakes within them, which leads to a reduction of costs External improvements focus on external customers to increase their satisfaction to ensure a larger market share and larger revenue as well, as emphasised by Dahlgaard, Kristensen, \& Kanji (1998). A certificate of quality can also be defined as a confirmation of the suitability of the quality system management to remedy non-quality. Crosby (1989) pointed out that quality results from prevention, and that the performance standard means zero defects. Consequently, all the above leads to satisfaction of the business organisation leadership, and this satisfaction influences the leadership's perception of the certificate of quality. However, the universality of the application of the same principles stipulated by the standard and the neglect of numerous specificities of the environment as well as the organisation itself made being average one of the associations with quality. On the other side, according to Bogataj and Žurga (2020), the quality management system with unified approach to leadership that is incorporated in the new ISO 9001 quality management system will influence not only on organization and processes but business results.

\section{Methodological Base}

Data on the number of certificates in the observed period were obtained from the ISO survey source (ISO, 2018). The fixed base index was used for the analysis of the fluctuation of the number of certificates in various years, while the chain index was used to analyse the relative change in the number of certificates during the observed period. A series of fixed base indices were converted into a series of chain indices so that each index was divided by the previous one, and the obtained coefficient was multiplied by 100 .

Two formulas are used for the calculation of analysed values, Formula 1 is for the calculation of the fixed base index and Formula 2 is for the calculation of the chain indices:

$$
\begin{aligned}
& I_{t}=\frac{Y_{t}}{Y_{b}} \times 100, \quad \mathrm{i}=1,2, \ldots . \mathrm{n} \\
& \quad \text { and } \\
& V_{t}=\frac{Y_{t}}{Y_{t-1}} \times 100, \quad \mathrm{i}=1,2, \ldots . \mathrm{n}
\end{aligned}
$$

What makes this study specific is that it was conducted directly through a questionnaire. The questionnaire was made for this study, and it was distributed to 269 business organisations with the ISO 9001:2015 certificates. The sample is 
a random stratified sample with a proportional allocation of elements per strata $n 1=50, n 2=150, n 3=100$ (micro, small, and medium and large business organisations). The sample was derived from the population of $\mathrm{N}=2529$ business organisations in the Republic of Croatia on 31 December 2015 with a confidence level of 95\%. The sample fraction estimation does not derogate from the population parameters for more than +-5\%. Žugaj, Dumičić, and Dušak (2006, 1999) used a representative method of sampling, and they have analysed sampling method techniques. In addition to the questionnaire and graphic representations, the paper uses numerical methods of the exploratory descriptive statistical analysis. Graphic representation of data is elaborated by Dumičić (2011c), while Dumičić and Palić (2011) discussed numerical measures of descriptive statistics. The ANOVA test and the chi-square test wer0065 used for analysing the statistical significance of differences among strata in the sample. Statistical data processing was conducted using the software SPSS, IBM (2018).

\section{Research Results and Discussion}

According to the latest data available in the ISO Survey in 2018, 2343 business organisations were certified to the ISO 9001:2015 standard on the Croatian market. The data presented in Table 1 show an initial increase in the number of certificates in 2008 and 2009. That number of certificates decreases in the decrease of business activities generated externally by the 2008 crisis, which also resulted in decertifications. Business organisations assessed that the cost of maintaining the certificate is higher than the positive effects of the business activities created by the certificate of quality. According to the statistical data of the High Commercial Court, which registers data on bankruptcy and winding up procedures from 1 July 2008 to 31 December
2009, 1.5 business organisations closed daily, which is one of the reasons for the decrease in the number of certificates in 2010 and 2011. The market gradually started recovering, and the number of certificates increased from 2012 with the highest increase in the number of certificates in 2014, when there were 2806 business organisations with a certificate of quality doing business on the Croatian market. Since 2014, the number of certificates has been in a mild decline, but it is still higher than the initial number from the year 2008. The smallest number of certified business organisations was in 2010 when 2102 certificates of quality were in organizations in the Republic of Croatia.

Table 1 shows that taking the year 2008 as the base year, the difference in the number of certificates per year is determined in comparison to the initial year of 2008. The most significant decrease in the number of certificates was in 2010 when 200 business organisations were left without a certificate of quality, a decline of $9 \%$ from the initial year 2008. The most significant increase in the number of certificates was in 2014 when the number of certificates increased by 504 (22\%) in comparison to the initial year of 2008 .

Throughout the observed period, the number of certificates fluctuated annually within the range of $-18 \%$ and $+22 \%$. The bottom limit of $-18 \%$ presents a valuable datum, since it shows the most significant decrease in the number of certificates, which could be relevant for the Covid-19 related crisis. When it comes to YOY \%, which measures the difference in the number of certificates year over year, it can be seen that the number of certificates in the last two years (2017 and 2018) declined by $10 \%$ and $2 \%$, respectively. Data indicate that the number of certificates in Croatia has been in decline, and observing the 2019 data when available will be valuable. The calculated fixed base index leads to the conclusion that the most significant change following the year 2008 was in the year 2014, with the maximum number of certificates in the observed period, and in the

Table 1. Fluctuation of the number of certificates from 2008 to 2018

\begin{tabular}{|c|c|c|c|c|c|c|c|c|c|c|c|}
\hline Country & 2008 & 2009 & 2010 & 2011 & 2012 & 2013 & 2014 & 2015 & 2016 & 2017 & 2018 \\
\hline Croatia (HR) & 2302 & 2567 & 2102 & 2117 & 2584 & 2636 & 2806 & 2529 & 2659 & 2381 & 2343 \\
\hline $\begin{array}{l}2008 \text { base- } \\
\text { absolute value }\end{array}$ & & 265 & -200 & -185 & 282 & 334 & 504 & 227 & 357 & 79 & 41 \\
\hline $\begin{array}{l}2008 \text { base - } \\
\text { percentage }\end{array}$ & & $12 \%$ & $-9 \%$ & $-8 \%$ & $12 \%$ & $15 \%$ & $22 \%$ & $10 \%$ & $16 \%$ & $3 \%$ & $2 \%$ \\
\hline $\begin{array}{l}\text { YOY \% - } \\
\text { year over year }\end{array}$ & & $12 \%$ & $-18 \%$ & $1 \%$ & $22 \%$ & $2 \%$ & $6 \%$ & $-10 \%$ & $5 \%$ & $-10 \%$ & $-2 \%$ \\
\hline $\begin{array}{l}\text { Index - } \\
\text { fixed base (It) }\end{array}$ & 100 & 111.51 & 91.31 & 91.96 & 112.25 & 114.50 & 121.89 & 109.861 & 115.50 & 103.43 & 101.78 \\
\hline Index YOY (Vt) & 100 & 111.51 & 81.88 & 100.71 & 122.05 & 102.01 & 106.44 & 90.12 & 105.14 & 89.54 & 98.40 \\
\hline
\end{tabular}


year 2012 when there was the smallest number of certificates in Croatia. The YOY index shows a change for the reference year in comparison to the previous year, and, in conclusion, the most significant fluctuation in the number of certificates was recorded from the year 2009 to the year 2010. The research indicated that the number of certificates in Croatia fluctuated depending on the observed year.

Figure 1 presents the trend in the observed period from 2008 to 2018, and the number of certified business organisations fluctuated between 2000 and 3000 .

The trend in the number of certificates showed that there was a fluctuation in the number of certificates, i.e. certified business organisations. Fluctuations are caused by business organisations abandoning certification or losing the right to be certified. Most business organisations lose their certificates due to the following circumstances: the quality system has not been implemented or was implemented partially, the quality system did not reflect the actual state of the organisation, the indicated non-compliance had not been remedied, an audit or recertification was not held within the required period, the certificate was inappropriately used, legal requirements had not been met or the business organisation did not manage to appeal the certificate suspension. Certification is abandoned when the estimated benefit from the certificate is smaller than was expected. The decision about whether a business organisation should abandon the certification or not depends on the leadership's satisfaction with the certified quality system. An efficient quality management system is based on the understanding of stakeholders' needs and expectations (Lazibat, Sutić \& Baković, 2013). The finding that a certain number of business organisations abandon certification or lose their certificate was the reason to study the leadership's satisfaction with the ISO 9001:2015 certificate. In their earlier study among the leadership of health organisations Žabica, Lazibat and Dužević (2014) proved that more than $80 \%$ of respondents do not see the benefits of implementing the quality management system in their business operations and service provision.

The study of the satisfaction with the ISO 9001:2015 certificate was conducted using a questionnaire among the leadership (the term leadership is taken from the ISO 9001 standard) of the micro, small, medium, and large business organisations. The respondents were authorised representatives acting as management board members or quality coordinators. The satisfaction with the certificate of quality in business organisations was graded on a scale, with grade 1 meaning "low satisfaction", grade 2 meaning "medium satisfaction", and grade 3 meaning "High satisfaction“. Statistical data processing showed that only $7.8 \%$ of respondents expressed a low level of satisfaction with the certificate, $41.3 \%$ showed medium satisfaction, and $50.9 \%$ showed high levels of satisfaction with the certificate. The analysis leads to the conclusion that every second respondent expressed a high level of satisfaction with the certificate.

Figure 1. The trend in the number of certificates from 2008 to 2018

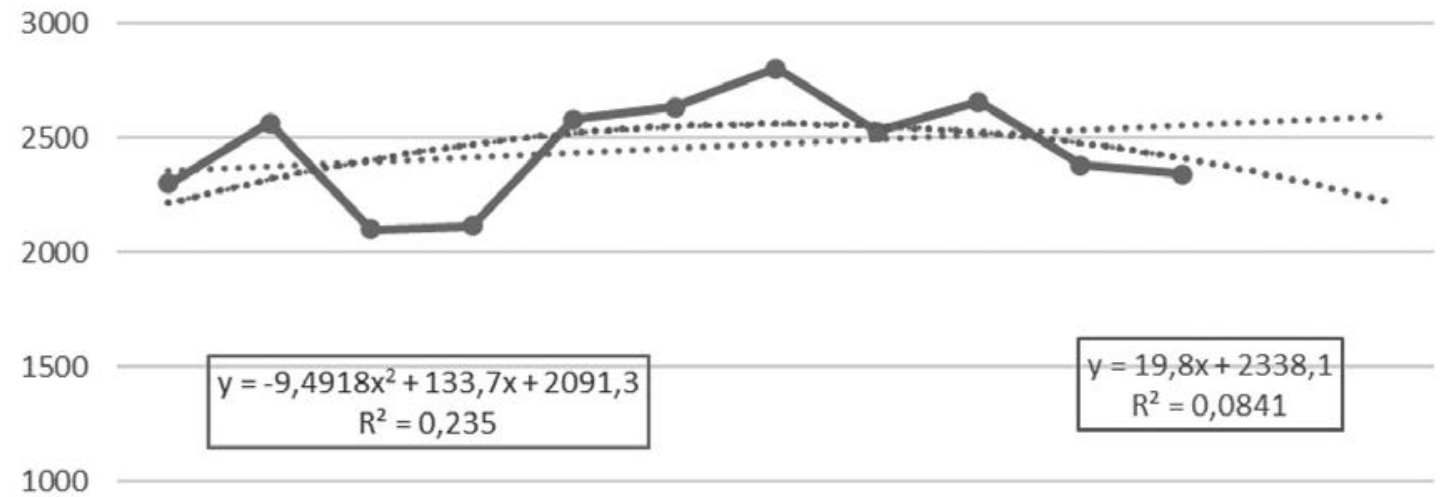

1000

500

0

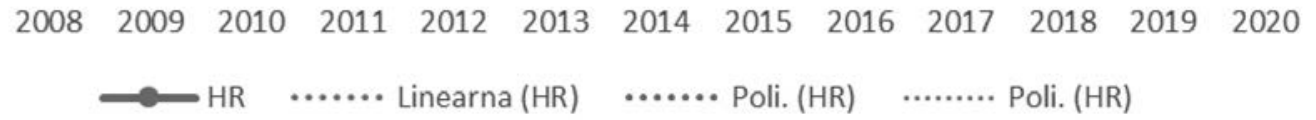


Table 2. The level of satisfaction of the leadership of business organisations with the ISO 9001:2015 certificate

\begin{tabular}{lccccc} 
& & Frequency & Percent & Valid Percent & Cumulative Percent \\
\hline & Low & 21 & 7.8 & 7.8 & 7.8 \\
\cline { 2 - 6 } $\begin{array}{l}\text { Evaluate your } \\
\text { satisfaction with } \\
\text { the 9001 certificate }\end{array}$ & Medium & 111 & 41.3 & 41.3 & 49.1 \\
\cline { 2 - 6 } & High & 137 & 50.9 & 50.9 & 100.0 \\
\cline { 2 - 6 } & Total & 269 & 100.0 & 100.0 & \\
\hline
\end{tabular}

Table 3. Descriptive statistics of the obtained value of satisfaction with the certificate based on the size of business organisations (arithmetic mean, standard deviation, and standard error)

\begin{tabular}{lccccc} 
& & $N$ & Mean & Std. Deviation & Std. Error \\
\hline & Micro & 94 & 3.43 & 0.810 & 0.084 \\
\cline { 2 - 6 } $\begin{array}{l}\text { Satisfaction with } \\
\begin{array}{l}\text { the certificate } \\
\text { per 3 strata }\end{array}\end{array}$ & Small & 125 & 3.41 & 0.774 & 0.069 \\
\cline { 2 - 6 } & $\begin{array}{l}\text { Medium } \\
\text { and large }\end{array}$ & 50 & 3.68 & 0.713 & 0.101 \\
\cline { 2 - 6 } & Total & 269 & 3.96 & 0.700 & 0.043 \\
\hline
\end{tabular}

Table 4. Testing the satisfaction with the ISO $9001: 2015$ certificate in relation to the size of the business organisation (the ANOVA test)

\begin{tabular}{lcc} 
Item & F & P \\
\hline Evaluate your satisfaction with the ISO 9001 certificate & 2,380 & 0.095 \\
\hline
\end{tabular}

Furthermore, Table 4 presents the results of the conducted ANOVA test $(\mathrm{F}=2.380, \mathrm{p}=0.095)$, which shows whether there is a statistically significant difference in the satisfaction with the ISO 9001 certificate of quality with the size of the business organisation. It was established that there were no statistically significant differences in relation to the size of the business organisation $(F=2.380, p=0.095)$.
Statistical significance was further tested using the chisquare test as presented in Table 5 and Table 6 . The chisquare test established the statistical significance of the difference in the satisfaction of the leaders among the three strata based on the size of business organisations.

Table 5. Testing the satisfaction with the ISO $9001: 2015$ certificate in relation to the size of the business organisation (chi-square test)

\begin{tabular}{|c|c|c|c|c|c|}
\hline & & Micro & Small & $\begin{array}{l}\text { Medium } \\
\text { and large }\end{array}$ & Total \\
\hline \multirow{2}{*}{ Low } & Count & 10 & 10 & 1 & 21 \\
\hline & $\%$ & $10.6 \%$ & $8.0 \%$ & $2.0 \%$ & $7.8 \%$ \\
\hline \multirow{2}{*}{ Medium } & Count & 37 & 54 & 20 & 111 \\
\hline & $\%$ & $39.4 \%$ & $43.2 \%$ & $40.0 \%$ & $41.3 \%$ \\
\hline \multirow{2}{*}{ High } & Count & 47 & 61 & 29 & 137 \\
\hline & $\%$ & $50.0 \%$ & $48.8 \%$ & $58.0 \%$ & $50.9 \%$ \\
\hline \multirow{2}{*}{ Total } & Count & 94 & 125 & 50 & 269 \\
\hline & $\%$ & $100,0 \%$ & $100.0 \%$ & $100.0 \%$ & $100.0 \%$ \\
\hline
\end{tabular}


Table 6. Testing the satisfaction with the ISO $9001: 2015$ certificate in relation to the size of the business organisation (chi-square test)

\begin{tabular}{lccc} 
& Value & df & $\begin{array}{c}\text { Asymptotic } \\
\text { Significance (2-sided) }\end{array}$ \\
\hline Pearson chi-square & $3,964^{a}$ & 4 & 411 \\
\hline
\end{tabular}

Table 6 presents the results of the chi-square test that tested the statistical significance of the difference in respondents' satisfaction with the size of the business organisation. No statistically significant difference was found $(x 2=3.964, p=0.411)$. Thus, the leadership's satisfaction with the certificate was not affected by the size of the business organisation, i.e. the complexity of their structures and processes.
One of the aims of this paper was to question the leadership of business organisations to determine whether they value business organisations that hold an ISO 9001:2015 certificate of quality. The goal was to study the perception of the quality certificate on the market by those who possess it. The perception of the certificate of quality was graded by grade 1 meaning "I do not appreciate”, grade 2 meaning “I am indifferent”, and grade 3 meaning "I appreciate“. Table 7 presents the results.

Table 7. Leadership's perception of business organisations with an ISO 9001:2015 certificate

\begin{tabular}{lccccc} 
& & Frequency & Percent & Valid Percent & $\begin{array}{c}\text { Cumulative } \\
\text { Percent }\end{array}$ \\
\hline \multirow{3}{*}{$\begin{array}{l}\text { Do you appreciate } \\
\text { the ISO 9001 } \\
\text { certificate? }\end{array}$} & I do not appreciate & 8 & 3.0 & 3.0 & 3.0 \\
\cline { 2 - 6 } & I am indifferent & 45 & 16.7 & 16.7 & 19.7 \\
\cline { 2 - 6 } & I appreciate & 216 & 80.3 & 80.3 & 100.0 \\
\hline
\end{tabular}

The results show that $80.3 \%$ of respondents appreciate business organisations with ISO 9001:2015 certificates. Sixteen point seven percent were indifferent while only $3 \%$ of the respondents did not appreciate business organisations with the certificate.
The ANOVA test, i.e. the variance analysis from Table 9 tested whether there was a statistically significant difference in the perception of the certificate of quality, i.e. whether the appreciation of the ISO 9001:2015 certificate depended on the size of a business organisation. It was de-

Table 8. Descriptive statistics of the perception of the certificate of quality concerning the business organisation size (arithmetic mean, standard deviation, and standard error)

\begin{tabular}{|c|c|c|c|c|c|}
\hline \multirow{4}{*}{$\begin{array}{l}\text { Do you appreciate business } \\
\text { organisations with the } \\
\text { ISO } 9001 \text { certificate? }\end{array}$} & Micro & 94 & 3.90 & 0.763 & .079 \\
\hline & Small & 125 & 3.91 & 0.684 & .061 \\
\hline & $\begin{array}{l}\text { Medium } \\
\text { and large }\end{array}$ & 50 & 4.16 & 0.584 & .083 \\
\hline & Total & 269 & 3.96 & 0.700 & .043 \\
\hline
\end{tabular}

Table 9. Testing the appreciation of business organisations having ISO 9001:2015 certificates (ANOVA test)

\begin{tabular}{lcc} 
Item & F & P \\
\hline Do you appreciate business organisations having the ISO 9001 certificate? & 2,656 & 0.072 \\
\hline
\end{tabular}


Table 10. Testing the appreciation of the ISO $9001: 2015$ certificate in relation to the business organisation size (chi-square test)

\begin{tabular}{|c|c|c|c|c|c|}
\hline & & Micro & Small & $\begin{array}{l}\text { Medium } \\
\text { and large }\end{array}$ & Total \\
\hline \multirow{2}{*}{ Not appreciated } & Count & 6 & 2 & 0 & 8 \\
\hline & $\%$ & $6.4 \%$ & $1.6 \%$ & $0.0 \%$ & $3.0 \%$ \\
\hline \multirow{2}{*}{ Indifference } & Count & 14 & 26 & 5 & 45 \\
\hline & $\%$ & $14.9 \%$ & $20.8 \%$ & $10.0 \%$ & $16.7 \%$ \\
\hline \multirow{2}{*}{ Appreciated } & Count & 74 & 97 & 45 & 216 \\
\hline & & $78.7 \%$ & $77.6 \%$ & $90.0 \%$ & $80.3 \%$ \\
\hline \multirow{2}{*}{ Total } & Count & 94 & 125 & 50 & 269 \\
\hline & $\%$ & $100,0 \%$ & $100.0 \%$ & $100.0 \%$ & $100.0 \%$ \\
\hline
\end{tabular}

Table 11. Testing whether the ISO 9001:2015 certificate was appreciated concerning the business organisation size (chi-square test)

\begin{tabular}{lccc} 
& Value & df & $\begin{array}{c}\text { Asymptotic } \\
\text { Significance (2-sided) }\end{array}$ \\
\hline Pearson chi-square & $9,463^{a}$ & 4 & 0.051 \\
\hline
\end{tabular}

termined that there was no statistically significant difference in the perception of the certificate of quality in relation to the business organisation size $(F=2.656, p=0.072)$.

The statistical significance of the difference was then tested using the chi-square test as shown in Table 10 and Table 11. The chi-square test was used to test the statistical significance of the difference in the perception of the certificate of quality by the leadership among the three strata determined based on the size of business organisations.

Table 11 presents the chi-square test results testing the statistical significance of the difference in appreciation of the ISO 9001:2015 certificate in business organisations of various sizes. It was established that there is no statistically significant difference $(x 2=9.463, p=0.051)$, although the results were very close to statistical significance.

\section{Conclusion}

The ISO 9001:2015 certificate of quality confirms that a business organisation has established a quality management system. The same requirements that the standard imposes on all business organisations in the world regardless of their size and business activities has resulted in the international reputation of the certificate of quality. Such quality standardisation is important since it facilitates the globalisation processes. This paper aimed to study the fluctuation of the number of ISO 9001:2015 certificates in Croatia and to evaluate the satisfaction and perception of the leadership with it. The fluctuation in the number of certified business organisations in the period between 2008 to 2018 was analysed using the chain index and the fixed base index. The greatest decrease in the number of certificates was registered in 2010 because of the economic crisis in 2008. The decrease was $18 \%$ from the previous year, i.e. there were 456 certificates less than the year before. The most significant increase in the number of certificates was in 2012 when the market recovered. There were 467 more certificates than the year before. The number of certificates fluctuated annually between $-18 \%$ and $+22 \%$. The lowest percentage of $-18 \%$ might be valuable because it could indicate the expected decrease in the number of certificates in the Covid-19-related crisis. On the other hand, due to a significant oscillation in the number of certificates at the annual level during the observed period, the researcher decided to analyse the satisfaction of the leadership with the ISO 9001:2015 certificate and their perception of the certificate of quality. The study indicated that almost every second respondent leading a business organisation with the ISO 9001:2015 certificate expressed high satisfaction with the certificate. Since business organisations differ in their structure and processes, the study also tested whether there was a statistically significant difference in satisfaction in the three size strata, micro, small and medium, and large, 
of business organisations. Testing was conducted using the ANOVA test and the chi-square test. The results showed that there is no statistically significant difference in the satisfaction of the leadership with the certificate based on the size of business organisations. For this analysis, the research question was formed in the way to determine whether business organisations with an ISO 9001:2015 certificate were appreciated. Business organisations that had implemented a certificate of quality in their business operations were appreciated by $80.3 \%$ of respondents, which confirms the reputation of the certificate of quality. Only 3\% of the respondents did not appreciate business organisations with a certificate of quality. Furthermore, no statistically significant difference in the perception of the certificate of quality with the size of the business organisation occurred. Eventually, the research showed that regardless of significant oscillations in the number of certified business organisations and based on the satisfaction of the most relevant stakeholders in the quality system, these certificates have a bright future.

The research was limited to the territory of Croatia and conducted with 269 certified business organizations. It will be interesting to conduct similar research in other countries. A higher number of certified business organizations in differ- ent countries would contribute to increasing the reliability of the results. A limitation of the research lies in the bias of the respondents. The respondents may have given insincere answers to present their quality management system as more efficient or exaggerate their satisfaction with it. The unwillingness of business organisations to participate in the survey was an additional limitation of the research. Respondents felt that providing answers could harm the reputation of their business organisation. It should be noted that GDPR (General data protection regulation) was also an obstacle that hindered the path to useful information through surveys. This study sheds light on the importance of leadership satisfaction because the satisfaction of leadership is the critical determinant of a quality management system and proof that a quality system creates business benefits for leadership. Only having a satisfied leadership is a confirmation that a quality system creates benefits for business organisations. In future research, it would be useful to see which elements of the quality management system leadership is most satisfied with and which have the most significant impact on generating benefits for business organisations. This study showed that the popularity of the ISO 9001 certificate is not fading due to the many benefits of a quality management system. It is the most well-known standard of business in the world.

\section{References}

Abu-Kharmeh, S. S. (2012). Evaluating the quality of health care services in the Hashemite Kingdom of Jordan. International Journal of Business and Management, 7(4), 195-205. https://doi.org/10.5539/ijbm.v7n4p195

Benner, M. J., \& Veloso, F. M. (2008). ISO 9000 practices and financial performance: A technology coherence perspective. Journal of Operations Management, 26(5), 611-629. https://doi.org/10.1016/j.jom.2007.10.005

Bogataj, V., \& Žurga, G. (2018). Consistency of Quality Management in Slovenian Organizations. Business Systems Research, 9(1) 78-92. https://doi.org/10.2478/bsrj-2018-0007

Cronin Jr, J. J., \& Taylor, S.A. (1992). Measuring service quality: A reexamination and extensions. Journal of Marketing, 56(3), 55-68. https://doi.org/10.1177/002224299205600304

Crosby, P. D. (1989). Kvaliteta je besplatna. Zagreb: Privredni vjesnik.

Črnjar, K., \& Vrtodušić H., A. (2013). Znanje i kvaliteta - uvjet konkurentnosti hoteljerstva Hrvatske. Poslovna izvrsnost/ Business Excellence, 7(2), 65-81.

Ćuzović, S., \& Ćuzović, Đ. (2012). Sustav upravljanja kvalitetom u trgovini - internacionalizacija marketinškog odnosa s potrošačima. Poslovna izvrsnost/Business Excellence, 6(1), 85-95.

Dahlgaard, J.J., Kristensen, K., \& Kanji, G.K. (1998). Fundamentals of Total Quality Management. Chapman \& Hall.

Dumičić, K. (2004). Istraživanje implementiranosti sustava kvalitete u hrvatskim poduzećima. Zbornik Ekonomskog Fakulteta u Zagrebu, Sveučilište u Zagrebu, Ekonomski Fakultet - Zagreb, 2(1), 101-122.

Dumičić, K. (2011c). Grafičko prikazivanje podataka. In Dumičić, K. and Bahovec, V. (Eds.), Poslovna Statistika, 53-92.Zagreb: Element.

Dumičić, K., Knego, N., \& Melvan, P. (2006). Europska perspektiva razvoja kvalitete u Hrvatskoj. In Drljača, M. (Eds.), Zbornik radova 7. hrvatske konferencije o kvaliteti: Kvaliteta i održivi razvoj, 12. Baška.

Dumičić, S., Kunović, V., \& Dumičić, K. (2005). Implementation of ISO 9001: 2000 system to market research agencies. South-east European Marketing Research Conference, 50-64. Belgrade.

Dumičić, S., Lazibat, T., Matić, B. (2005). Quality system implementation and,arket structure: sample survey of Croatian companies. Ekonomski pregled, 59(9), 615-633.

Dumičić, K., \& Palić, I. (2011). Brojčane mjere opisne statistike. In Dumičić, K. and Bahovec,V. (Eds.), Poslovna statistika, 97-167. Zagreb: Element. 
International Organization for Standardization (ISO). Retrieved from https://isotc.iso.org/livelink/livelink?func=ll\&objld=18808772 \&objAction=browse \&viewType=1

Juran, J. M., \& Gryna, F.M. (1999). Planiranje i Analiza Kvalitete. Zagreb: Mate.

Lazibat, T. (2001). Poznavanje Robe u Trgovini. Zagreb: Mikrorad.

Lazibat, T., Sutić, I., \& Baković, T. (2013). Mjerenje kvalitete visokoobrazovne usluge iz perspektive studenata. In Drljača, M. (Eds.) Zbornik radova 14. Međunarodnog simpozija o kvaliteti: Kvalitetom protiv recesije: 20(2), 373-392. Rovinj.

March, J. G. (1991). Exploration and exploitation in organizational learning. Organizational Science, 2(1), str. 71-87. https://doi. org/10.1287/orsc.2.1.71

Škafar, B. (2019). (In)effectiveness of quality management systems and models of excellence in practice. Management, 24(1), 7184. https://doi.org/10.30924/mjcmi.24.1.5

Zambelli, S., \& Rajić, D. (2014). Analiza sustava kvalitete u certificiranim i necertificiranim hrvatskim vanjskotrgovinskim poduzećima. Poslovna Izvrsnost/ Business Excellence, 8(1), 83-100.

Zelenika, R. (2001). Prometni sustavi. Rijeka: Ekonomski fakultet u Rijeci.

Žugaj, M., Dumičić, \& K., Dušak, V. (1999). Temelji znanstvenoistraživačkog rada; Metodologija i metodika. Varaždin: Fakultet organizacije i informatike.

Žugaj, M., Dumičić, \& K., Dušak, V. (2006). Temelji znanstvenoistraživačkog rada; Metodologija i metodika. Varaždin: Fakultet organizacije i informatike.

Žabica, S., Lazibat, T., \& Dužević, I. (2014). Implementacija sustava upravljanja kvalitetom na različitim razinama zdravstvene djelatnosti. Poslovna Izvrsnost/Business Excellence, 8(1), 9-23.

\section{Analiza nihanja števila potrdil ISO 9001:2015 v Republiki Hrvaški in ocena zadovoljstva vodstev poslovnih organizacij s potrdilom}

\section{Izvleček}

Potrdilo o kakovosti ISO 9001:2015 je danes najbolj priznan standard kakovosti na svetu. Standardizirana kakovost je postala nujna konkurenčna prednost na trgu za vse resne poslovne organizacije. Nihanje števila potrdil o kakovosti kaže, $\checkmark$ kolikšni meri so podjetja pripravljena svojim strankam zagotoviti kakovost izdelkov in storitev ter kako hitro je domači trg standardiziran in vključen v svetovno gospodarstvo. V prispevku so predstavljeni rezultati dveh empiričnih študij. Prva se osredotoča na analizo nihanja števila potrdil ISO 9001:2015 v obdobju od 2008 do 2018, druga pa želi ugotoviti zadovoljstvo vodstva s potrdilom. Študija je pokazala, da v opazovanem obdobju število potrdil o kakovosti na Hrvaškem letno niha med $-18 \%$ in $+22 \%$. Na letni ravni določeno število podjetij izgubi potrdila ali se odloči za njihovo ukinitev. Prav zato je bila na vzorcu 296 certificiranih poslovnih organizacij izvedena študija stopnje zadovoljstva vodstva s potrdilom o kakovosti ISO 9001:2015.. Študija je dokazala, da vodstvo kaže visoko stopnjo zadovoljstva s potrdilom o kakovosti in da ceni poslovne organizacije s potrdili o kakovosti. Navedeno dokazuje, da imajo potrdila o upravljanju kakovosti svetlo prihodnost ne glede na letna nihanja števila certifikatov.

Ključne besede: potrdilo, standard, potrdilo ISO 9001:2015, sistem kakovosti, vodstvo, poslovne organizacije 